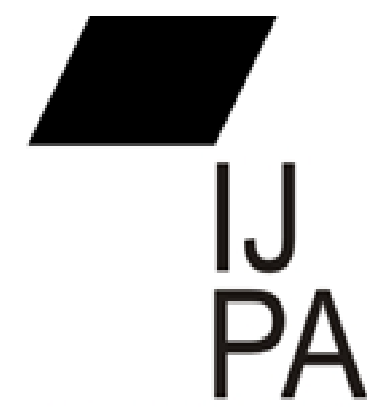

ISSN $2460=0369$

\section{KAJIAN KEBIJAKAN SUMBERDAYA ALAM BERBASIS PADA EKOLOGI POLITIK}

\author{
Agus Lukman Hakim \\ Ilmu Administrasi Niaga, \\ Sekolah Tinggi Ilmu Administrasi Banten \\ aguslukman.hakim@stiabanten.ac.id
}

Abstract: The study of natural resource management policy is concentrated more on the implementation and evaluation of natural resource policies, whereas failure and lack of optimal public policies are mostly caused by public policy formulations that are not systematic, partial and have not touched the substance of the matter. SDA policy theory explains that ecological problems cannot be solved partially but with a multi-level approach by examining actors who play a role in the preparation of policy regulations so that the problems of natural resource management can no longer be analyzed with a technical approach but are more appropriate to use a political aspect approach.

Keywords: Resource Policy, Political ecology, Polital aspect.

Abstrak: Kajian kebijakan pengelolaan sumberdaya alam (SDA) lebih banyak dikonsentrasikan pada implementasi dan evaluasi kebijakan SDA padahal gagal dan kurang optimalnya kebijakan public lebih banyak disebabkan karena formulasi kebijakan public yang tidak sistematis, parsial dan belum menyentuh pada substansi persoalan. Teori kebijakan SDA menjelaskan bahwa persoalan ekologi tidak bisa diselesaikan secara parsial tetapi dengan pendekatan multi aras dengan mengkaji aktor-aktor yang berperan dalam penyusunan regulasi kebijakan sehingga persoalan pengelolaan SDA tidak bisa lagi dianalisis dengan pendekatan teknis tetapi lebih tepat menggunakan pendekatan political aspect.

Kata kunci: Kebijakan SDA, Ekologi Politik, Aspek Politik. 


\section{PENDAHULUAN}

Pengelolaan SDA selama ini diekspoitasi seperti mesin ekonomi yang dimanfaatkan kebutuhan manusia. Orientasi pengelolaan SDA mengacu pada pembangunan dan neoliberalisme menjadikan arah pembangunan cenderung ekonomi sentris. Dampaknya adalah SDA dijadikan sebagai objek konsumtif demi pertumbuhan dan pembangunan ekonomi sehingga terjadi kegiatan eksplorasi dan eksploitasi SDA sebesar-besarnya yang berdampak terjadinya kerusakan lingkungan dan kutukan sumberdaya pada masyarakat di lingkungan sekitarnya (Jati 2013). Shiva (1995) mengkritisi pola pembangunan di dunia ketiga dengan memberikan istilah sindrom eksploitasi. Setidaknya terdapat dua sindrom eksploitasi, yaitu adanya kepemilikan barang privat menggantikan barang publik dalam pengelolaan sumber daya alam. Hal tersebut terjadi karena kepemilikan publik tidak menguntungkan secara ekonomis. Dampaknya adalah kepemilikan privat terus bertambah sehingga mendorong perilaku konsumtif masyarakat untuk memuaskan keinginanya namun cenderung eksploitatif yang berefek negatif pada lingkungan dan terciptanya tragedy of the commons (Hardin 1968). Fenomena tersebut terjadi karena kebutuhan manusia yang melebihi kapasitas dan berdampak pada kerusakan alam. Sindrom kedua adalah perilaku aparatur birokrasi pemerintahan yang melakukan upaya legalisasi kebijakan dengan memberikan perizinan barang-barang publik dengan alasan peningkatan pendapatan negara dan pertumbuhan ekonomi. Kondisi tersebut menjadikan lemahnya peran negara mengatur dan membatasi aktifitas ekonomi yang berdampak negatif bagi masyarakat (Jati 2011). Pasar seharusnya didorong sebagai eksekutor dalam menciptakan pertumbuhan ekonomi. Fenomena tersebut melahirkan tumbuhnya kajian dan penelitian terkait dengan ekologi politik.

\section{TINJAUAN PUSTAKA}

Teori ekologi politik berkembang pesat seiring dengan kajian lingkungan yang mulai menggabungkan dinamika lingkungan lokal dengan pendekatan ekonomi dan politik. Studi ekologi politik berpendapat bahwa keputusan pengelolaan SDA tidak 
bisa dipahami hanya dari sudut pandang teknis yang memprioritaskan efisiensi tapi terkait dengan kekuasaan (Arsel 2009). Persoalan ekologi di berbagai belahan bumi perlu dianalisis dengan pendekatan multi aras serta dengan berbagai bidang kajian dan garapan, termasuk kajian politik karena belum ada partai politik yang menempatkan prioritas pelestarian lingkungan dan sumberdaya dalam platform partai sehingga kajian ekologi telah banyak bergeser dari kajian klasik ke kajian yang dinamis dan menantang dengan menganalisis aspek politik. Ekologi politik menemukan dua ruang, yaitu ruang konflik dan kekuasan. Ruang konflik terkait proses penyusunan dan penetapan kebijakan dan keputusan politik yang melibatkan berbagai kepentingan. Ruang kekuasan merupakan ruang pemimpin dalam menjalankan kebijakan yang ditetapkan dalam ruang konflik (Dharmawan et al 2007). Para pakar mendefinisikan ekologi politik sebagai: "...environmental change and ecological conditions are (to some extent) the product of political processes...". Kondisi lingkungan merupakan produk dari proses politik sehingga tidak lepas dari dialektika dalam politik ekonomi. Ideologi profit-maximizing economy yang dianut oleh para aktor selalu mengacu pada paradigma benefit and cost analysis dalam praktek politik ekonomi (Dharmawan et al 2007). Proses kerusakan sumberdaya khususnya di negara dunia ketiga terjadi karena politik oligarki yang memungkinkan elaborasi antara politisi, birokrasi dan pengusaha dengan melakukan dua strategi, yaitu membuat regulasi legal maupun melalui proses legislasi yang mengandung unsur korupsi. Pola tersebut telah menjadikan krisis ekologi yang dahsyat dan merusak SDA yang tersedia.

Berbagai pendekatan teknis telah dikembangkan dalam menyelesaikan persoalan perusakan sumberdaya. Persoalan sumberdaya yang muncul di berbagai belahan bumi telah diberikan solusi dengan pendekatan teknis. Pencemaran sungai akibat pertambangan dicarikan solusi dengan melakukan inovasi teknologi yang ramah lingkungan. Persoalan minimnya produksi ikan dan rusaknya terumbu karang diselesaikan dengan pengembangan daerah perlindungan laut (Satria 2007). Penyelesaian tersebut tentu tidak salah namun belum memberikan solusi ke akar persoalannya sehingga kerusakan lingkungan selalu terjadi dan cenderung meningkat.

3 Available online at website: http://journal.uta45jakarta.ac.id/index.php/admpublik/index Copyright (C) 2018 | IJPA | E-ISSN:2460-0369 
Hal tersebut diakibatkan kerusakan lingkungan sangat terkait dengan akses pemanfaatan dan kontrol terhadap sumberdaya. Keterkaitan tersebut menjadikan kajian pengelolaan sumberdaya dan lingkungan sangat terkait dengan kajian ekonomi politik yang menganalisis kajian pengelolaan sumberdaya dan lingkungan dianalisis dalam perspektif sosial politik. Kajian dan analisis teori ekologi politik menjelaskan pola pengelolaan sumberdaya yang berasal dari interaksi antara sistem alam dan sistem sosial, termasuk didalamnya terdapat kekuasan ekonomi dan politik (Arsel 2009).

Teori ekologi politik berkembang sejak tahun 1960an dengan mengembangkan aspek politik dalam ekologi. Perkembangan kajian ekologi politik semakin pesat setelah dicetuskan oleh Russet pada tahun 1967 dilanjutkan Eric Wolf tahun 1972, Miller tahun 1978, Cockburn dan Ridgeway pada tahun 1970 (Satria 2007). Teori ekologi politik menurut Bryant dan Bailey (2001) menekankan lima pendekatan yang saling terkait. Pendekatan pertama, ruang analisisnya lingkungan secara khusus yang berkaitan dengan dampak manusia terhadap lingkungan. Pendekatan kedua terkait dengan basis pada ekologi politik. Analisis wacana sangat dominan dalam pendekatan ini. Pendekatan ketiga menfokuskan kajian ekologi dengan politik melalui studi kasus pada wilayah tertentu. Pendekatan keempat menjabarkan kajian ekologi politik dengan karakteristik sosial ekonomi masyarakat, seperti gender. Pendekatan kelima menfokuskan pada kebutuhan dan kepentingan serta konflik antar aktor.

Teori ekologi politik menurut Bryant dan Bailey (2001) terbagi pada dua periode. Periode pertama, tahun 1970an hingga 1980an. Periode ini kajian tentang ekologi politik mengacu pada teori Neo Marxian yang menjelaskan hubungan masyarakat lokal dan kerusakan lingkungan dengan kekuatan ekonomi dan politik supra desa dan merupakan kritik terhadap Neo-Malthusian dan ekologi budaya. Kajian ekologi politik pada periode ini menggunakan analisis struktural yang melihat konflik akibat dari proses produksi global. Periode kedua, tahun 1980an hingga 1990an. Kajian ekologi politik pada periode ini mengacu pada teori Neo Weberianisme, teori gerakan sosial dan teori feminisme, dan serta merupakan kritik terhadap Neo-Marxism. Fokus kajian pada perubahan pada berbagai tingkatan 
sebagai hasil interaksi seluruh aktor yang memiliki kekuasaan dengan tekanan analisis pada ketidakseimbangan kekuasaan berbagai aktor, dan motif serta kepentingan dari aktor tersebut.

Berbeda dengan Bryant (1997), Robin (2012) membagi studi perkembangan ekologi politik pada beberapa bagian:

a. Tahun 1979, dengan dimotori oleh Cockburn dan Ridgeway. Pengembangan kajian ekologi dengan menggambarkan gerakan radikal di Amerika, Eropa barat, dan negara industri maju lainnya. Kajian tersebut menjelaskan gambaran lengkap tentang degradasi lingkungan perkotaan dan perdesaan yang diakibatkan berbagai kegiatan perusahaan akibat kesalahan pengelolaan SDA sehingga menimbulkan respon negatif dari para penggiat sosial.

b. Tahun 1997, dimotori oleh pemikiran Blaikie dan Brookfield. Penelitian dan kajian ekologi politik dianalisis dalam perspektif ekologi dan politik. Perebutan SDA antara masyarakat dengan perusahaan berdampak perubahan lingkungan yang mempengaruhi produksi lokal dan regional dalam kekuatan ekonomi politik global.

c. Pemikiran berikutnya dikembangkan oleh Greenberg dan Park pada tahun 1994. Ia menemukan bahwa ekologi politik tak lepas dari kajian ekonomi politik sehingga perlu dianalisis tentang distribusi kekuasaan.

d. Kajian dari Peet dan Watts 1996 menjelaskan bahwa ekologi politik merupakan perpaduan antara studi ekologi yang berasal dari ilmu sosial dengan ekonomi politik sehingga dalam analisisnya dijelaskan fenomana munculnya gerakan dari masyarakat dan LSM tentang perlawanan terhadap pemerintah dan perusahaan akibat pengelolaan SDA yang merusak lingkungan.

e. Tahun 1996, Hempel menggambarkan pendekatan ekologi politik sebagai kajian dan penelitian tentang relasi antara peran politik dengan lingkungan serta dampaknya bagi lingkungan dengan tujuan menggambarkan tindakan para aktor yang menyusun dan mengimplementasikan kebijakan yang berdampak pada kerusakan lingkungan. 
f. Tahun 2000, Watts menjelaskan kajian ekologi politik terkait dengan akses dan kontrol SDA serta dampaknya terhadap lingkungan serta konflik lingkungan khususnya pertarungan pengetahuan, kekuasaan, politik, dan keadilan. Pakar yang lain, Scott dan Sullivan menjelaskan ekologi politik terkait motif aktifitas manusia yang mendorong kerusakan lingkungan dan menggambarkan dimensi politik terkait lingkungan.

Kajian ekologi politik semakin dikuatkan dengan pandangan modernisme (Beck 1992). Pemikiran modernisme berawal dari kesadaran masyarakat terhadap resiko. Pendekatan modernisme berpendapat bahwa bencana di masa depan harus diminimalisir dengan mereduksi resiko yang dapat merusak kehidupannya seperti bencana alam. Keberadaan bencana akan merusak capaian pembangunan yang telah terealisasi. Filosofi pendekatan ini mengacu pada manusia harus bersahabat dengan lingkungan agar dapat mengelola dampak/resiko dari kerusakan lingkungan sehingga harus mengontrol perilaku dirinya dalam menggunakan sumberdaya dan mencari alternatif penggunaan sumberdaya yang memiliki resiko kecil bagi kehidupan manusia. Forsth (2003) menjelaskan kajian ekologi politik tidak terlepas dari pengaruh kapitalisme terhadap lingkungannya. Beberapa isu dominan dalam kajian ekologi politik, seperti degradasi dan marginalisasi, konflik lingkungan, konservasi dan pengendalian, identitas lingkungan dan gerakan sosial serta objek politik dan aktor (Robbins 2012).

Fenomena pengelolaan SDA yang cenderung eksploitatif mendorong terjadinya kutukan sumberdaya. Daerah yang kaya sumberdaya, mayoritas penduduknya miskin akibat eksploitasi sumberdaya dari daerah perdesaan menuju pusat perekonomian di daerah perkotaan. Stiglitz (2007) menjelaskan fenomena kutukan sumberdaya disebabkan pengelolaan sumberdaya memerlukan modal dan teknologi yang canggih sehingga memberikan peran besar pada negara dan korporasi untuk menguasainya. Negara menjalankan peran sebagai regulator dan korporasi menjadi pelaksana proyek, yang berdampak pada marginalisasi peran masyarakat lokal. Kondisi tersebut menjadikan minimnya partisipasi masyarakat dalam pengelolaan SDA dan kontrol yang rendah.

6 Available online at website: http://journal.uta45jakarta.ac.id/index.php/admpublik/index Copyright (C) 2018|IJPA| E-ISSN:2460-0369 


\section{METODE PENELITIAN}

Tulisan ini menggunakan analisis deskriptif kualitatif dengan basis tinjaun pustaka melalui literasi jurnal dan buku. Kajian ini mencoba untuk memberikan gambaran pengelolaan SDA dengan pendekatan yang baru, yaitu pendekatan ekologi politik. Teori ekologi politik yang digunakan adalah analisis teori ekologi politik dengan menjelaskan pola pengelolaan SDA yang berasal dari interaksi antara sistem alam dan sistem sosial, termasuk didalamnya terdapat kekuasan ekonomi dan politik. Beberapa teori ekologi politik yang digunakan mengacu pada Russet pada tahun 1967 dilanjutkan Eric Wolf tahun 1972, Miller tahun 1978, Cockburn dan Ridgeway pada tahun 1970 (Satria 2007) serta Bryant dan Bailey (2001) menekankan lima pendekatan yang saling terkait.

\section{PEMBAHASAN}

\section{Pengelolaan SDA dan Aktor yang terlibat}

Pengelolaan SDA oleh negara yang bersifat top-down cenderung menjadi pola baku yang terjadi di negara dunia ketiga. Kondisi tersebut menjadikan sifat hegemoni negara terhadap SDA semakin mudah dalam berkolaborasi dengan korporasi sehingga menafikan peran masyarakat yang berdampak terjadinya resistensi penduduk setempat. Tarikan kepentingan aktor dalam pengelolaan SDA dianalisis oleh Bryant dan Bailey (1997) dengan mengembangkan tiga asumsi mendasar dalam persepektif ekologi politik. Pertama, biaya dan manfaat yang terkait dengan perubahan lingkungan yang tidak merata. Perubahan lingkungan tidak mempengaruhi perbedaan politik, sosial, dan ekonomi untuk pendistribusian. Kedua, distribusi yang tidak merata berpengaruh pada ketidaksetaraan sosial dan ekonomi. Pada konsep tersebut, ekologi politik mengarah ke ekonomi politik yang melekat sebagai perubahan dalam kondisi lingkungan yang mempengaruhi politik dan ekonomi status quo. Ketiga, proporsi biaya dan manfaat yang tidak merata akan berdampak pada ketidaksetaraan yang sudah ada dan berdampak pada politik terkait hubungan kekuasaan. 
Bryant dan Bailey (1997) menyatakan analisis aktor dan hubungannya dengan lingkungan digunakan untuk menganalisis peran serta kepentingan aktor yang berdampak pada lingkungan. Analisis aktor juga digunakan untuk membandingkan peran dan kepentingan aktor yang berbeda sehingga dapat memahami motivasi, kepentingan dan tindakan para aktor. Analisis aktor juga digunakan untuk menggambarkan peran dan interaksi aktor terkait dengan konflik aktor dengan lingkungannya. Analisis aktor dari Bryant dan Bailey (1997) mengacu pada pendekatan neo-Marxist yang menganalisis peran aktor dalam pengaturan ekologi (Novenanto 2015). Aktor yang terlibat dalam perubahan lingkungan yaitu negara, lembaga multilateral, pengusaha, NGO lingkungan, dan aktor lokal/masyarakat lokal (Bryant dan Bailey 1997).

Penelitian Blaikie (1985) menjelaskan persoalan erosi tanah bukan hanya masalah pengelolaan lahan tapi sangat terkait dengan marginalisasi peran aktor lokal sehingga adanya dominasi kekuatan kaum kapitalis terhadap aktor lokal (petani). Blaikie dan Brookfield (1987) menggambarkan kerusakan lingkungan hidup sangat terkait dengan kajian ekologi dan ekonomi politik yang mencakup hubungan masyarakat dengan sumberdaya terkait lahan lahan, terkait dengan aktor dan peran kelompok masyarakat di dalamnya.

Gerakan masyarakat merupakan reaksi terhadap pengelolaan SDA yang cenderung destruktif dan eksploitatif. Masyarakat lokal melakukan upaya perlawanan terhadap pengelolaan SDA yang cenderung eksploitatif. Gerakan perlawanan masyarakat lokal biasanya dilakukan oleh masyarakat yang menjunjung tinggi adatistiadat dan kearifan lokal untuk menjaga kelestarian alam. Pembentukan gerakan dengan ideologis eko-populisme bertujuan untuk menyeleraskan kehidupan manusia dengan lingkungan sekitarnya sehingga masyarakat menjadi agen kontrol pengelolaan sumberdaya yang menyejahterakan secara ekonomi dan ekologi (Jati 2013).

Marginalisasi peran aktor lokal khususnya masyarakat menimbulkan dampak pada gerakan perlawanan yang diinisiasi masyarakat lokal seperti dilakukan oleh komunitas masyarakat adat, Tehri Garhwa. Komunitas Garhwa berpandangan hutan sebagai tempat menyediakan air, bercocok tanam, penyedia bahan bangunan yang

8 Available online at website: http://journal.uta45jakarta.ac.id/index.php/admpublik/index Copyright (C) 2018 | IJPA | E-ISSN:2460-0369 
harus dijaga kelestariannya serta merupakan sumber penghasilan komunitas tersebut. Pemerintah India melakukan deforestasi karena pegunungan Himalaya menghasilkan kayu terbaik di dunia. Masyarakat melakukan perlawanan dan protes terhadap kebijakan perizinan tersebut dengan memeluk pohon (Chipko). Gerakan tersebut akhirnya tersebar dengan dukungan LSM ke seluruh India bahkan mendapat dukungan dunia sehingga Pemerintah India menghentikan kegiatan deforestasi (Jati 2013). Peran masyarakat yang kuat didukung oleh gerakan LSM dapat mempengaruhi kebijakan pemerintah sebagaimana studi Ardhian (2016).

Pendekatan tersebut menjelaskan relasi kuasa para aktor yang disebabkan keberadaan objek tertentu, seperti SDA berupa tanah dan air. Konklusi analisis tersebut cenderung sejenis, yaitu: negara tidak pernah aktif mengatasi konflik agraria, karena terdapat motif akumulasi modal. Negara cenderung lebih mendiamkan konflik berlanjut dibandingkan menuntaskannya, lebih mendorong mekanisme pasar. Ketika negara berperan, kebijakannya cenderung represif dan menjadi pendukung kapitalis dengan alasan pembangunan untuk kepentingan umum walaupun bertentangan dengan kehendak masyarakat lokal. Penawaran solusi dari negara cenderung bersikap tegas terhadap konflik sehingga menempatkan posisi negara seolah-olah satu-satanya menjadi problem solver terhadap konflik yang ada (Novenanto 2015).

Strategi yang dilakukan aktor dalam mengontrol lingkungan aktor lain melalui beberapa cara. Strategi pertama, aktor mengontrol akses aktor lain terhadap sumber daya seperti tanah, air dan lainnya dengan tujuan mendominasi manfaat sumberdaya. Kedua, mengarahkan aktor lain melalui program sosial dan pro lingkungan. Ketiga, mengarahkan lingkungan aktor pihak lain dengan melalui wacana dan gagasan seperti mengarahkan ide serta pemikiran aktor lain (Bryant 1997).

\section{PENUTUP}

Berdasarkan pembahasan di atas, penulis menarik simpulan sebagai berikut:

1. Pengelolaan sumberdaya alam berbagai belahan bumi perlu dianalisis dengan pendekatan multi aras serta dengan berbagai bidang kajian dan garapan, termasuk kajian politik yang melahirkan keilmuan ekologi politik

9 Available online at website: http://journal.uta45jakarta.ac.id/index.php/admpublik/index Copyright $($ C 2018|IJPA | E-ISSN:2460-0369 
2. Pendekatan relasi kuasa para aktor dalam pengelolaan sumberdaya alam sering melahirkan kondisi negara tidak pernah aktif mengatasi konflik antar aktor swasta dan masyarakat. Negara cenderung lebih mendiamkan konflik berlanjut dan lebih mendorong mekanisme pasar. Kalaupun negara berperan, kebijakannya cenderung represif dan menjadi pendukung kapitalis dengan alasan pembangunan untuk kepentingan umum walaupun bertentangan dengan kehendak masyarakat lokal.

Berdasarkan simpulan di atas, penulis menyarankan sebagai berikut: Pengelolaan sumberdaya tidak lepas dari peran berbagai aktor dan kepentingannya. Oleh karena itu, pemimpin negara yang dipilih rakyat harus tegas dalam mendorong pengelolaan SDA yang berpihak pada kepentingan rakyat serta mampu menyelesaikan konflik kepentingan dari berbagai aktor yang terlibat

\section{DAFTAR PUSTAKA}

Ardhian D. 2016. Dinamika Peran dan Strategi LSM dalam Arena Politik Lingkungan Hidup (Kasus Kebakaran Hutan dan Lahan). IPB [ID] Thesis: Bogor.

Arsel M. 2009. Ekologi Politik, Dimana Ekonominya. Jurnal Tanah Air: 11-17.

Beck U. 1992. Risk Society: Toward New Modernity. London (UK): Sage Publication.

Blaikie P. 1985. The Political Economy of Soil Erosion in Developing Contries. Journal Review of African Political Economy. 33:113-115.

Blaikie P, Brookfield H. 1987. Land Degradation and Society. London (UK): Matheue

Bryant LR, Bailey S. 2000. Third World Political Ecology. Routledge. London (UK) and New York (US). 20 (5): 561-58.

Dharmawan AH, Adiwibowo S, Saharudin, Sumarti T, Satria A, Sunarti E, Hardinsyah, Sunito S, Soetarto E, Sitorus MTF, Mardiana R. 2007. Bunga

Rampai Ekologi Manusia. Editor Soeryo Adiwibowo. Bogor (ID): Fakultas Ekologi Manusia IPB. 
Forsth T. 2003. Critical Political Ecology. New York (US): Routledge.

Hardin G. 1968. The Tragedy of The Commons. Science 162 No. 3859:1243-1248.

Jati WR. 20 April 2011. Pembangunan Gerus Kearifan Lokal. Kompas, hlm.6 diakses agustus 2017.

. 2013. Manajemen Tata Kelola Sumber Daya Alam Berbasis Paradigma Ekologi Politik. POLITIKA: Jurnal Ilmu Politik, 3(2), 98-111.

Novenanto A. 2015. Manusia Dan Tanah: Kehilangan Dan Kompensasi Dalam Kasus Lapindo. BHUMI: Jurnal Agraria dan Pertanahan, 1(1).

Robbins P. 2012. Political Ecology: A Critical Introduction. Second Edition. WileyBlackwell Publishing.

Satria A. 2007. Ekologi Politik. Fondasi, Teori dan Diskursus Ekologi Manusia. Prosiding

Shiva V. 1995. "Globalism, Biodiversity, and The Third World". Helena NorbergHodge (ed.) The Future of Progress: Reflections on Environment and Development. Devon: Green Books.

Stiglitz JE. 2007. Berkelit dari Kutukan Sumber Daya Alam, terjemahan Surya Kusuma. Bogor (ID): The Samdhana Institute. 